\title{
Lessons Learned from My Daughter's First-Year Experience
}

\section{Denise L. Rode}

Those of us who are professionals in the fields of orientation, transition, and retention are accustomed to providing advice and counsel to prospective/new students and their families. We communicate the value of making wise decisions on everything from how to select a college to getting along with roommates to staying safe on campus. We tout the overwhelming body of research and literature on the importance of student engagement to students' identity development, academic success, and retention. We take our professional responsibilities to our constituents seriously, but what happens when our own kids approach the point of college? Does the knowledge and advice we offer freely to others assist our own students-and us-when the time comes?

This Perspectives article is a case study of one parent's transition with her daughter to the college world. Although this unscientific "study" is based on an $N$ of 1, I hope it will provide some insight for those who will be navigating this crossing in the future, a moment of support for those who are living it right now, and some fond (or not-so-fond) memories for those who have been there.

Visiting Campuses: Many of us in this field believe strongly that the best way to evaluate a college is to visit it. Viewbooks, Web sites, and blogs all have value, but there's nothing like setting foot on a campus to assess the match between student and institution. With this in mind, I tried to set up college visits during my daughter's junior year in high school and the following summer, to no avail. When my daughter's senior year began, pressing project deadlines, band and dance competitions, and college entrance exams left her with no time for college visits. In the midst of senior year craziness, she decided to apply to colleges and then visit the ones where she was admitted and which were among her top 2-3 choices. Her strategy worked, but it caused her mom some heartburn along the way. Lesson learned: Students have their own timetables for exploring college options, and they don't necessarily mesh with ours.

The Admissions Process: A steadfast believer in letting students do things for themselves, I began to get nervous during my daughter's senior year as application deadlines grew near and the forms were not completed. Most of the

Denise L. Rode (drode@niu.edu) is Editor of The Journal of College Orientation and Transition, the Director of Orientation \& First-Year Experience at Northern Illinois University, and a member of the adjunct faculty in college student development at DePaul University in Chicago. 
schools to which she applied required well-developed essays. Complicating the situation were her grandfather's illness and death during the prime application period. She met the online application deadlines and mailed paper copies of her letters of recommendation at the eleventh hour, but not without help from her parents, who stuffed envelopes, licked stamps, and supplied last-minute proofreading. Lesson learned: Don't hover, but help your student organize the application process and stay on track for deadlines. Offer some assistance, but don't do it for them.

After four months of waiting and watching the mailbox and e-mail, the good news arrived: She was admitted to her first-choice university. She called her mom at work, proudly saying, "In the fall of 2008, I will be a freshman at XYZ University." Her parents breathed a huge sigh of relief and sent in a hefty deposit to secure her place in the Class of 2012. Lesson learned: Somehow, it all works out in the end.

Orientation: My daughter's institution is very different from the one where I work-in size, control, and demographics. I expected her orientation experience to be very different from the program I direct, and it was. Her course selection and scheduling was an online process and allowed for very little student input-even in terms of the course load for the first semester. This concerned her less than it did me, as I am accustomed to advising sessions taking place during summer orientation and students registering for courses themselves. Because students come to XYZ University from across the United States and from many other countries, orientation is accomplished en masse just before the fall term.

Parent orientation, too, differed from the small-group approach on my campus. It was difficult not to make comparisons between my philosophy of orientation and the "XYZ way." Lesson learned: Try to focus on your role as a parent/family member at orientation, rather than as an orientation professional from another institution. Stay open to the possibility that XYZ U has a solid rationale for how it conducts orientation that may differ from your approach. Who knows - you may even take away an idea or two to enhance your own program.

Major and Course Selection Process: Having watched some faculty members on my home campus "help" their students select courses, I've seen how easy it is to co-opt the process and develop the "perfect" schedule for your student. After all, you know higher education and you know your student-who better than you to bring your professional and personal knowledge together to assist your student? It can be very difficult to step back and let your student make his or her own decisions, in collaboration with the academic advisor, especially when your student defers to your judgment. Lesson learned: I found it most effective to share with my daughter the "ups and downs" from my own first year (e.g., "I registered late and found myself in 8 a.m. classes five days a week," and "I took 18 hours my first 
semester and did fine academically, but I had no time for anything else."). What surprised me was that my daughter was actually listening. Case in point: When she registered for Latin her freshman year, I questioned why she would choose to study an ancient language. She responded, "You always told me that your Latin background helped you read and write better."

On-Campus Living: One of the toughest challenges of the first year for my only child was learning to live with two roommates with different lifestyles from hers. They differed significantly in how they approached their academic work and study time. Having grown up in the shadow of a large university, my daughter had witnessed first-hand some of the pitfalls of the first year and had made a conscious decision to avoid the party scene. This was not the case for many students within her residence hall, and early in her first semester, one of them landed in the hospital with alcohol poisoning. Lesson learned: Although there was some "drama" during the first year (and it's easy to be caught up in it, especially for moms), the roommates learned to work through many differences and remain close friends (although not roommates) as sophomores.

Getting Involved: As a student affairs practitioner who embraces the value of student engagement in the campus community, I was disappointed and concerned when my daughter held back from getting involved in residence hall activities and the vibrant campus life at XYZ University. She auditioned and was selected for a dance team but did not seem very involved, preferring to spend most of her time studying. Lesson learned: My daughter was very similar to many other academically-oriented, first-year students I have worked with. She waited until she had experienced success in her course work within the competitive environment at XYZ U. Only now, as a sophomore, is she beginning to take on a leadership role in her residence hall and to seek out service opportunities on campus and in the community. In developmental terms, she tested out her competence in the classroom and now is branching out to explore her competence in other areas.

Disappointments and Setbacks: Every first-year student will encounter times when things don't go his or her way. For my daughter, the first let-down was not being selected for the prestigious marching band she had wanted to join since her first visit to the campus at age 4 . This jolt came after she had been recruited for the band and had spent three days of new student orientation at band camp. A second "bump" came when she had a dance injury which put her in a walking cast for several winter months. A third came in the spring when she decided to drop Organic Chemistry a month before the end of the academic year when many other freshmen also dropped the course. Lesson learned: I was able to hold back from intervening on the first two situations, but I did contact my student's first-year of studies advisor on the third issue as this decision had financial and time-to-degree repercussions. Choose your "helicopter parent" moments carefully and only with advance notification to your student! 
First-Year Seminar: After the aforementioned Organic Chemistry course was dropped, my daughter filled the gap with a first-year seminar/college success course late in her freshman year. As one who oversees the coordination of these courses on my own campus, I had not been able to convince my student of their value in her first semester. Said daughter grudgingly admitted after the course was finished that she had learned a few things. Lesson learned: Students may initially ignore our advice but may see its value at a later point-when they are ready.

Summer Plans: As the end of her first year approached, my daughter confirmed her summer plans: take two summer courses at the "home town" institution where her mother works, practice dance, travel to Washington, DC, and help her dad at his business (unfortunately, she did not have a paying job). Lesson learned: With both my daughter and I on the same campus, we each glimpsed each others' worlds for a couple of months. We came away with a better appreciation (on her part) of my work with new students and their families and (on my part) a stronger sense of her dedication and competence as a student. I realized that my student had matured in her critical thinking skills, her ability to research and write, and to hold her own in communicating with faculty members. She had positively resolved many of the first-year developmental issues that most students face and was ready to move on to the challenges of the sophomore year.

Starting Again: Having successfully navigated the sinuous waters of the freshman year, my daughter returned to school this fall with a greater sense of purpose and confidence. In many ways, her first-year experience as a student was paralleled by my first-year experience as a college parent. Living through her first year has informed my practice in a variety of ways. In teaching my first-year course, I am better able to relate to the new students' experiences and emotions. Having faced the "empty nest," I encourage my students to stay connected to their parents but, at the same time, to achieve a healthy level of independence. In teaching master's level students, I find myself using anonymous situations that my daughter experienced to illustrate a point about a position on the Perry Scheme of Ethical and Intellectual Development or a level of moral reasoning in Gilligan's "In a Different Voice." I believe I have become a better, more empathic administrator and teacher having learned lessons from my daughter's first-year experience.

Back to the original question: Does having a background in the field of orientation, transition, and/or retention help when the time comes to launch our own children/family members off to college? My contention is yes and no. We can be steeped in the college development literature, have a working familiarity with research on new students, and read the latest popular books on college transitions. These resources will help us anticipate what may occur during 
our students' first year. Ultimately, our intuition, coping strategies, and intimate and unique knowledge of first-year students will guide us in the freefall that is the first-year experience. 